\title{
Universities and the Market for Intellectual Property in the Life Sciences
}

Walter W. Powell
Jason Owen-Smith

\begin{abstract}
The realms of science and technology in the life sciences are converging through the commercialization of university research. Major changes in the mandate of research universities were facilitated by both federal legislation that has promoted technology transfer, and the increased reliance of business firms on university research and development $(R \& D)$. This article discusses the primary factors that are blurring the division of labor between industry and academia in the life sciences, and analyzes the consequences for universities of treating knowledge as intellectual property. Universities' efforts to enhance the commercial value of life sciences research is causing increased politicization of government research funding, a growing winner-take-all contest between the "have" and "have-not" universities, and subtle but potentially profound changes in the culture of academic research.
\end{abstract}

\section{INTRODUCTION}

Over the past decade there has been a remarkable shift in the division of labor between universities, industry, and the federal government. In our view, this transformation is most pronounced in the life sciences and the commercial fields of medicine, pharmaceuticals, and biotechnology. The post-Cold War focus of federal science and technology policy on "competitiveness" has been noted by many observers, and the intensified interest in basic research and collaborative product development by large private corporations in various high-technology fields has been widely studied. But the accompanying change in the mandate of research universities toward a greater focus on commercializing research findings is much less understood. Our goal in this article is to enhance the understanding of the ways in which the relationship between universities and the private economy has changed, particularly in the life sciences. We highlight the primary forces that have blurred the traditionally distinct roles of the academy and industry, illustrating these trends with data from

Journal of Policy Analysis and Management, Vol. 17, No. 2, 253-277 (1998)

(C) 1998 by the Association for Public Policy Analysis and Management

Published by John Wiley \& Sons, Inc.

CCC 0276-8739/98/020253-25 
the life sciences. We review several explanations for this transformation, and conclude with a discussion of its consequences for both public policy and the institutional role of universities as generators and disseminators of basic knowledge.

Throughout much of the post-World War II era there was a relatively clear distinction between basic and applied research, with the former the domain of the university and the latter the turf of business. The federal government, outside of defense-related research, supported the creation of an infrastructure for basic research and, through the National Science Foundation (NSF) and the National Institutes of Health (NIH), funded individual scientists as well. University research was basic in the sense that it aimed to understand phenomena at a fundamental level. The NSF defines basic science as research that has as its objective a fuller knowledge or understanding of the subject under study, rather than a practical application thereof. But this focus, as Rosenberg and Nelson [1994] suggest, has never meant that basic research was inattentive to the pull of important technological problems and policy objectives. Indeed, Geiger [1986] has shown that the "knowledge-plus" focus of U.S. universities has been a "quiet" reality for much of this century, and not simply a post-World War II phenomenon. Moreover, Ben-David [1977] has observed that U.S. universities have long had a more practical orientation than universities in the United Kingdom or Germany.

Still, universities focused more on the R side of the R\&D (research and development) continuum, while much of industry eschewed basic research because the payoffs were either too long-run or too difficult to appropriate. The great bulk of industry R\&D was focused on shorter term problem solving. ${ }^{1}$ To be sure, basic research flourished in a handful of large corporations, such as AT\&T, Kodak, Dupont, and IBM, whose dominant market positions cushioned research budgets from market pressures. But recent changes in government regulation and intensified competition have ended the era of great corporate labs, and the centralized corporate R\&D lab may never actually have been as widely employed as typically assumed [Rosenbloom and Spencer, 1996].

Dasgupta and David [1987, 1994] argue that the realms of science and technology are separated more by their social organization and reward structure than by the actual character of their work. Despite the similarities in the methods of their work, scientists and technologists enter their respective realms "precommitted" to different norms and rules of the game. For scientists, priority of discovery is the goal, and publication the means through which new knowledge is shared in a timely fashion [Merton, 1957]. The public nature of scientific knowledge encourages its use by others, and in so doing, increases the reputation of the researcher [Merton, 1988; Stephan, 1996]. In contrast, patents are the coin of the realm in the technologist's world. Rewards are pecuniary and the incentive to divulge new information quickly is not as potent.

Our argument is that the separation of the realms of science and technology no longer holds in the life sciences. The formerly independent, if fragile, system is today fully interdependent as universities have become much more oriented to the commercialization of research. Burton Weisbrod's Introduction to this issue cautions that "nonprofit organizations confront a dilemma, as does public

\footnotetext{
${ }^{1}$ For an excellent historical survey of the relationship between universities and industry, see Rosenberg and Nelson [1994].
} 
policy toward them: how to balance pursuit of their social missions with financial constraints, when additional resources may be available from sources that would distort mission." With respect to research universities, we argue that income-generating activities that were formerly ancillary are taking on much greater salience. This shift is not,we argue, driven by an urgent need for new sources of financing but rather is a result of changing incentives that favor increased efforts at the commercialization of research.

This remaking of the institutional division of labor between universities and the private economy is both recent and profound. We begin our survey of the broad contours of this changed landscape by focusing briefly on key policy changes at the federal level. We then turn to the corporate sector, noting the significant changes in the structure of the firm, particularly with regard to how access to new knowledge is organized. The role of universities is considered next, and we document the increasing commercialization of research, especially in the life sciences, and the new status of knowledge as intellectual property. We think it is important, however, to recognize that the relationship between university research and commercial technology development varies considerably across academic fields and industries, and thus our analysis of the life sciences is not necessarily generalizable to other areas. We, therefore, heed Mowery and Rosenberg's [1993] caution that "no single model or description of the constraints, advantages, and disadvantages of such collaboration is likely to be accurate for all university-industry collaborations" (p. 53).

\section{A CHANGED LANDSCAPE}

\section{Government Policy}

With the ending of four decades of rivalry and conflict with the Soviet Union, the rationale for federal science and technology expenditures has been reoriented toward programs that enhance economic "competitiveness" [Cohen and Noll, 1994; National Academy of Sciences, 1992; Slaughter and Rhoades, 1996]. There is a growing federal view that research universities can and should play a larger and more direct role in assisting industry and promoting national competitiveness. Universities are being urged by the federal government to seek a more direct partnership with business in the development and commercialization of new technologies.

The shift in federal policy-from basic research to increased concern over its application-is reflected in legislation, funding plans, and joint agreements. Most notable on the legislative front was the 1980 Patent and Trademark Amendments (Public Law 96-517), also known as the Bayh-Dole Act. This legislation allowed universities, nonprofit institutions, and small businesses to retain the property rights to inventions deriving from federally funded research. The intent of Congress was to promote collaboration between commercial concerns and nonprofit organizations, including universities. The 1984 Public Law 98-620 expanded the rights of universities more broadly by removing restrictions in Bayh-Dole and permitting universities to assign their property rights to others. ${ }^{2}$ The Stevenson-Wydler Act of 1980 (Public Law 96-

\footnotetext{
2 Jonathan Cole, provost of Columbia University, writing in a 1993 Daedalus issue on "The Amer-
} ican Research University" terms Bayh-Dole "prescient" and notes that "annual revenues from pat- 
480) and its 1986 amendments; the Cooperative Research Act of 1986 (Public Law 98-462); the National Competitiveness Technology Transfer Act of 1989 (Public Law 101-189); and the Clinton administration's 1993 "defense conversion initiative," which opened up formerly off-limits defense-related research to commercialization, have all followed the path laid by Bayh-Dole to remake federal policy to enhance the commercialization of research at universities. ${ }^{3}$

These legislative changes sparked a considerable upsurge in licensing, as well as rapid growth in the number of university-industry research centers (UIRCs), cooperative research and development agreements (CRADAs), federally funded research and development centers (FFRDCs), and industry-university research consortia. A significant change in funding policies has accompanied these initiatives. ${ }^{4}$ At the NSF, numerous programs have been developed to promote university-industry collaboration, and funding in some engineering and science and technology fields requires that NSF-supported centers have an industrial component. Stigler [1993] suggests that the NSF has found it "easier to explain large-scale projects and research centers to Congress than to argue convincingly for the diffuse benefits of a broad-based funding of individual projects ..." (p. 172). The impact of these UIRCs is considerable: Cohen, Florida, and Goe [1994] estimate that 19 percent of university research is now carried out in programs that involve close linkages with industry.

Cohen and Noll [1994] argue that the competitiveness rationale for federal research support has two strong consequences. One, there is greater privatization of both the selection (the review process) and the results (intellectual property rights) of research. The review process is increasingly "privatized" by requiring corporate participation (as directed by eligibility criteria), by assigning industry responsibility for the evaluation of technical merits, and by including the feasibility of commercialization and marketing plans as key points of evaluation. Two, there is now increased collaboration between U.S. firms and research organizations, and federal research funds now go to a wider array of research organizations than just research universities.

\section{Business Strategy}

The embracing of the competitiveness rationale at the federal level reflected a widespread perception among policymakers that U.S. corporations were faring less well in international competition. Although the United States was widely regarded as the world leader in scientific research, U.S. industry in the 1980s looked vulnerable indeed. Universities and industry were chided for their failure to transfer basic research into commercial development. Within the large corporation, there was growing recognition that firms had become much less self-sufficient in their ability to generate the science and technology necessary

ents and licenses (at Columbia) have risen from roughly $\$ 4$ million to $\$ 24$ million over the past five years ... and over the next decade, we could see these figures grow to as much as $\$ 75$ million a year" [Cole, 1993, p. 31]. In congressional hearings reviewing the consequences of the Bayh-Dole Act, university presidents and officials testified to the success of the legislation in promoting technology transfer and generating jobs, particularly in biotechnology [U.S Congress, Senate, Subcommittee on Patents, Copyrights, and Trademarks, 1994].

${ }^{3}$ Lee [1994] provides a detailed survey of legislation fostering technology transfer.

${ }^{4}$ For example, the federally funded national laboratories are now expected to generate more of their operating budgets through the sale of technology [Roessner and Wise, 1994; Schriesheim, 1990-1991]. 
to fuel economic growth [Nelson, 1990; Von Hippel, 1988]. As a result, there is now much greater reliance on external sources of R\&D [Badaracco, 1991; Hagedoorn, 1993; Hamel, 1991; Saxenian, 1994]. The causes of this transformation are myriad, involving an indissoluble combination of corporations' need to access sources of expertise located outside organizational boundaries, pressures to compete with global rivals that do little research internally but are quick to exploit the developments of others, and the tremendous scale of investment required to commercialize novel new technologies [see discussion in Powell, 1990, pp. 314-318; Powell, Koput, and Smith-Doerr, 1996, pp. 116122].

In many rapidly developing areas of technology, research breakthroughs are so broadly distributed across both disciplines and institutions that no single firm has all the necessary capabilities to keep pace [Powell, 1996]. Consequently, in such fields as advanced television systems, biotechnology, computers, optics, and semiconductors, firms are turning to cooperation with former competitors, and to partnerships with universities and government institutes. Rosenbloom and Spencer [1996] capture these developments aptly: "What was once a race has become more like a rugby match" (p. 70). They anticipate a "diminishing role for corporate laboratories as the wellspring of innovation," and suggest that the "seeds of new technological advance will probably sprout more often in university or government laboratories" (pp. 70-71). The private firms that are best able to exploit such new developments are those with both the most extensive external connections and the strongest internal capabilities for evaluating the quality of research done elsewhere [Powell, Koput, and Smith-Doerr, 1996].

Many observers have noted that this transformation of corporate research is most pronounced in the biopharmaceutical field, where there is a complex intermingling of government and university research, small firm initiative, and large firm development and marketing muscle. Federal research funding has supported much of the basic science underlying the new biotechnology, while top researchers in universities and in the intramural branches of the NIH have made the pioneering discoveries. Science-based small firms, either spun off from universities or with extensive academic linkages, have played a key role in new product development. Alliances among universities, small start-ups, and established pharmaceutical corporations have proven to be effective vehicles for the commercialization of new medical treatments.

\section{Universities}

Changes in both federal policy and corporate practice have consequently reshaped the external environment and incentive structure of research universities. No longer are universities just the providers for industry of basic research knowledge and a trained labor force, skilled in the newest technologies. Universities have become, in the words of NSF Division Director Daryl Chubin [1994], "creators and retailers of intellectual property" (p. 126). High-quality research, Chubin suggests, has multiple components-a basis for scientific knowledge, innovative technology available for transfer, and the expertise embodied in faculty and research staff. Etzkowitz and Webster [1995] observe that "science and property, formerly independent and even opposed concepts referring to distinctively different kinds of activities and social spheres, have been made contingent upon each other through the concept of intellectual 
property rights" (pp. 480-481). This commercialization of knowledge makes universities key contributors to economic innovation, both as, in Chubin's [1994] language, "resource and catalyst" (p. 126).

Not only is university research now evaluated more extensively for its commercial application, universities themselves are increasingly viewed as "engines of economic development" [Feller, 1990]. The successes of universityindustry affiliations have played a key role in the development of such hightechnology-based industrial districts as Silicon Valley; Route 128 (in Massachusetts); Austin, Texas; and the Research Triangle in North Carolina [Rosegrant and Lampe, 1992; Smilor, Kozmetsky, and Gibson, 1988]. Numerous analysts have observed that innovation has become dependent on a region's technological infrastructure [Feldman, 1994; Feldman and Florida, 1994; Jaffe, Trajtenberg, and Henderson, 1993; Krugman, 1991; Romer, 1986]. Thus, the success of a relatively small number of universities in contributing to local economic development has changed the expectations for nearly all universities. Now every governor wants the next Silicon Valley in his or her backyard.

In turn, some universities have decided that they can play a more aggressive financial role than just being an incubator of new knowledge. They seek to share in the income that may be generated by their new discoveries. Hence, we are witnessing the growth of universities as venture capitalists [Matkin, 1990]. The progression from incubator of ideas, to patent licensing and technology transfer, to science parks, and finally to equity ownership is based in part on the recognition that in fast-developing fields patents do not easily "capture" intellectual property [Merges and Nelson, 1990]. Negotiating for equity in start-up companies is often easier for universities to do than licensing their research findings. But the most compelling factor to universities is the prospect of large financial returns.

The life sciences represent the cutting edge of these developments, in part because of the large number of start-up companies created with the assistance or direct involvement of academic researchers [Zucker, Darby, and Brewer, 1994]. The biotechnology industry is remarkably clustered in but a few areasSan Diego, the Bay Area, Boston, Seattle, and to a lesser extent, Philadelphia and Houston-with close proximity to major universities, research-oriented hospitals, and cancer treatment facilities. ${ }^{5}$ Physical, intellectual, and economic integration between firms and universities is so pronounced that they constitute a common technological community [Powell, 1996].

\section{THE LIFE SCIENCES REPRESENT THE LEADING EDGE}

We stress that the nature of industry-university-government relationships are largely idiosyncratic to particular disciplines. Indeed, one reason that the life sciences are rather unusual is that biotechnology represents a novel case of an industry that was developed inside the university. The initial discoveries were made by university scientists, and they played a leading role in the introduction

\footnotetext{
${ }^{5}$ Although university faculty played a key role in biotechnology's emergence, the continuing involvement of academic researchers does not appear to be geographically localized. In research we are doing, we find that networks of collaboration are not locally based [Koput, Powell, and SmithDoerr, 1997] and Audretsch and Stephan [1996] report that biotech scientist-firm linkages are typically nonlocal.
} 
and development of the new ideas. Biotechnology has thus largely collapsed the distinction between basic and applied science: Fundamental new discoveries, such as gene therapy or the identification of a fat gene, have immediate scientific and medical importance as well as enormous commercial relevance. Of course, while the life sciences may be the leading edge of commercial ventures, there are novel efforts underway in all branches of universities to exploit their "assets" in order to enhance revenue generation. Athletics are the most visible example, but selling seats at poetry readings and various forms of professional education, conferences, and outreach programs are other signs of greater attention to commercial activities.

We document the blurring of the division of labor between universities and industry, marshaling a range of evidence to demonstrate the convergence of the public and private sectors. We first present summary data on university patenting and on royalties derived from university licensing. We then look at the increased role of industry funding of university research in the health sciences fields, illustrating this trend with a snapshot of the burgeoning field of genomics. Next, we examine the notable changes in the labor market for biological scientists, and describe how a common scientific community has evolved that spans universities and industry. Finally, we briefly look at two universities, Stanford and Johns Hopkins, that are at the forefront of research and its commercialization in the life sciences.

\section{Patenting}

One way to examine university commercialization efforts is to analyze universities' propensity to patent. Table 1 illustrates the limited activity of universities

Table 1. Top patent classes for university patenting.

\begin{tabular}{rlr}
\hline Class & & $\begin{array}{r}\text { Number of } \\
\text { patents }\end{array}$ \\
73 & Measuring and testing 1969-1973 & 56 \\
128 & Surgery & 32 \\
435 & Chemistry: molecular biology and microbiology & 31 \\
424 & Drug: bio-affecting and body treating compositions & 31 \\
204 & Chemistry: electrical and wave energy & 28 \\
514 & Drug: bio-affecting and body treating compositions & 27 \\
56 & Harvesters & 26 \\
423 & Chemistry of inorganic compounds & 25 \\
324 & Electricity: measuring and testing & 23 \\
310 & Electrical generations and motors & 23 \\
& & \\
435 & Chemistry: molecular biology and microbiology & 863 \\
514 & Drug: bio-affecting and body treating compositions & 789 \\
424 & Drug: bio-affecting and body treating compositions & 518 \\
128 & Surgery & 306 \\
250 & Radiant energy $\quad 241$ \\
530 & Chemistry: peptides or proteins & 229 \\
324 & Electricity: measuring and testing & 192 \\
204 & Chemistry: electrical and wave energy & 188 \\
364 & Electrical computers and data processing systems & 178 \\
73 & Measuring and testing & 171 \\
\hline
\end{tabular}

Source: Nawtional Science Board [1996, pp. 252-253]. 
in the 1969-1973 period, but by 1989-1994 patenting by universities increased dramatically. Moreover, note the three patent classes where university efforts were most significant: All three are in the life sciences. Henderson, Jaffe, and Trajtenberg [1995] have noted that, from 1965-1992, total U.S. patenting grew by less than 50 percent; our analysis of NSF data for the period 1969-1994 shows an increase on the part of universities of over 1100 percent. And a much greater number of universities is now involved: In 1965, 96 patents were issued to 28 universities, whereas in 1992 nearly 1500 patents were granted to 150 universities [Henderson, Jaffe, and Trajtenberg, 1995]. In short, university patenting has grown rapidly while industry activity has increased modestly, and the life sciences have been at the forefront of university efforts.

A 1992 U.S. General Accounting Office report [U.S. GAO, 1992] suggests that these changes in patenting propensity reflect greater university focus on commercially relevant technologies and increased industry funding of university research. More specifically, the increased drive to patent is a direct response to the Bayh-Dole legislation that facilitated university retention of property rights to federally funded research. The U.S. GAO survey of 35 universities found that technology developed in whole or in part with NSF and NIH funding accounted for 73 percent of the $\$ 113.1$ million that the universities received in license income in 1989 and 1990; and that the typical licensees were small U.S. business in biotechnology or pharmaceutical corporations.

\section{Licensing and Corporate Support of RED}

University revenues derived from patenting and licensing have been growing annually, reaching nearly $\$ 255$ million in 1994 . A sizable percentage of licensing revenues are derived from life science applications. For example, the Massachusetts Institute of Technology (MIT) is very active in this area, and despite not having a medical school, a recent survey [Guterman, 1996] of technology transfer there reports biotechnology constitutes about half of MIT's exclusive licenses. The commercial benefits of licensing are obvious. Successful product development by a firm generates royalties to a university and the inventor in question. But the rationales for licensing a discovery are diverse, and create very different challenges for universities.

Consider the following three motivations, each of which characterizes an important aspect of university licensing of innovative research. A diagnostic test-such as for Wilm's tumor, which affects only a few hundred young children-has limited commercial value but can be licensed broadly to speed its clinical development, while freeing the faculty member to continue basic research. In contrast, some licensing is exclusive and entrepreneurial. Productive faculty convert discoveries into the platform for companies that they spin off from their university research, and the university licenses the professor's discovery to the professor's company. Such an arrangement prevents the loss of valuable faculty to industry. Indeed, in our research on the biotechnology industry, we have encountered numerous examples of faculty at leading research universities who have developed two or more companies while maintaining their university positions. At the same time, this process involves a partial "loss" of faculty insofar as their energy and creativity is shifted to firm-related work.

A third key motivation for licensing is to utilize discoveries as magnets to draw sponsored research into the university. Clearly this has been a powerful trend in the life sciences, generating enhanced funding for faculty, providing 
employment opportunities for graduate students, and promoting a new dialogue between business and industry — feedback that might otherwise be absent from both basic science and corporate product development. The first example of broad licensing allows a professor to continue his or her research, the second-involving exclusive licensing-enables a professor, but not necessarily the university, to have the best of both worlds, so to speak, and the third example attracts corporate funding to the university.

The growing industry role in health-related research is illustrated in Figure 1. Note that since 1980 both industry and federal support for health research has grown rapidly; but, around 1988, industry spending surpassed the contri-

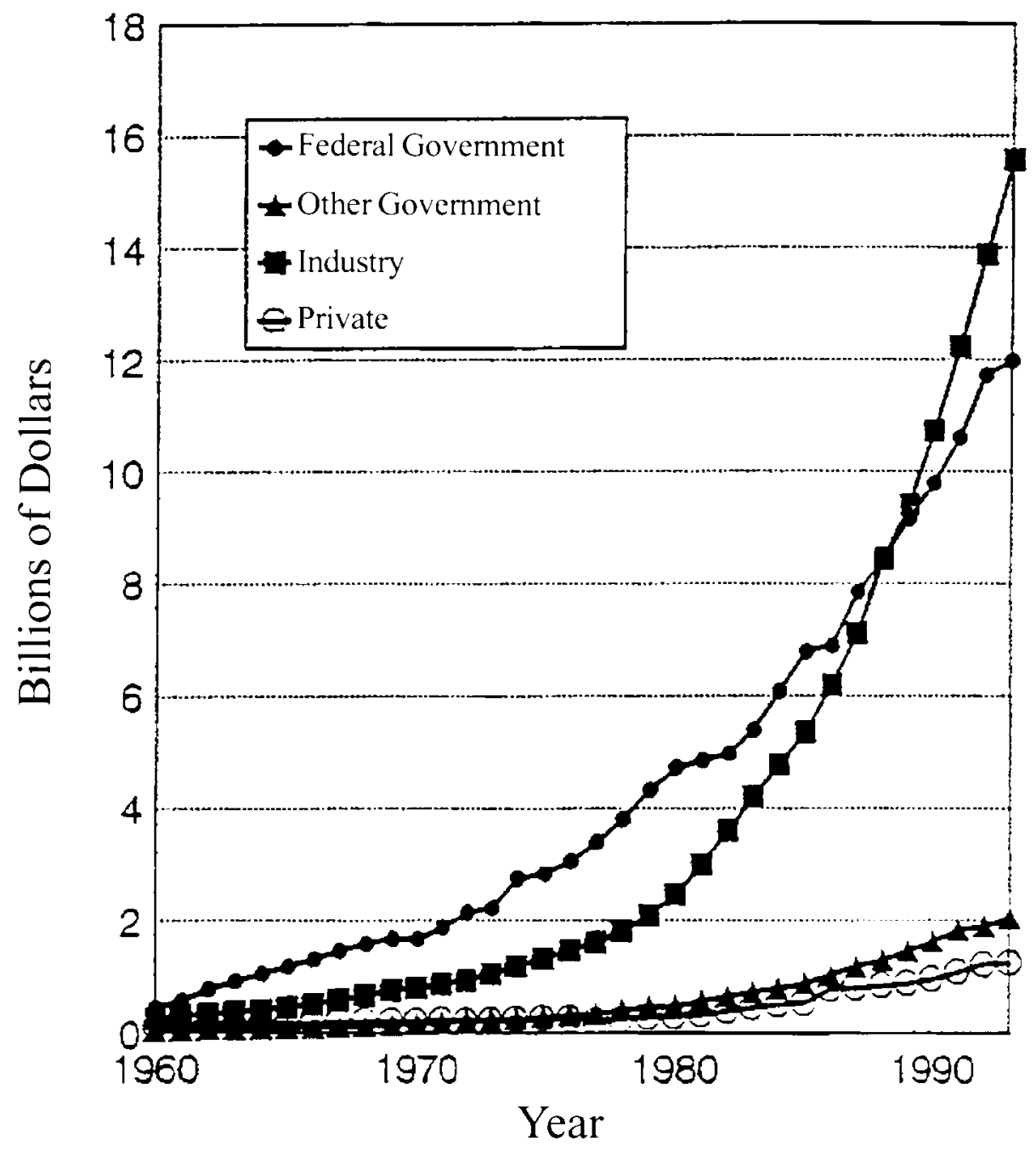

Figure 1. National support for health research and development, by source, 1960-1993. Source: Provided to authors by the National Institutes of Health (NIH) Division of Planning and Evaluation, Planning and Policy Research Branch. 
bution of government. To be sure, the great bulk of medical industry R\&D is still done "in-house," but in the context of declining corporate research spending across U.S. industries, the biopharmaceutical sector is a striking counterpoint. Figures for 1995 suggest federal funding for medicine and health on the order of $\$ 13$ billion, and an industry contribution of $\$ 15$ billion (NIH Economics Roundtable, Executive Summary, January 1996). When looked at from the viewpoint of a single university, we can see just how significant corporate support from the biopharmaceutical sector is. At the University of Arizona, in 1995 , the top 50 corporate sponsors of research and development gave $\$ 25$ million to the university. Nearly one third of these sponsors are biotech or pharmaceutical companies. In addition, a ranking of all U.S. firms in terms of R\&D expenditures as a percentage of sales shows that eight of the top ten spenders on R\&D are biopharmaceutical firms, with two modest-sized biotech companies at the very top-Genentech and Amgen. ${ }^{6}$

Genomics is the broad label for one of the hottest fields in the life sciences. The race to map the sequence of the human genome has triggered a parallel race to determine gene function. The emerging area of functional genetics includes efforts to discover genes for specific diseases, to correct genetic defects with gene therapy, and to discover tools (ranging from combinatorial chemistry to bioinformatics) to manage the flood of genetic information. Industry-university collaborations in this area are both commonplace and so complex that a weekly scorecard is needed to keep track of who is working with whom. Knowledge is advancing at an explosive rate in this area, and appealing hypotheses for intervention in unmet medical needs are abundant, albeit highly uncertain. One attraction of genomics and related new technologies is that they offer a powerful means to accelerate the drug discovery process. Large pharmaceutical companies, fearful of being left behind as new technologies for rapid high-volume screening of new chemical entities are developed, have either acquired, taken equity positions in, or joined in collaborations with many of the leading small companies. The appeal of the smaller biotech companies is based on both their intellectual property related to genomics and their closeness to university-based research. Larger, established biotech firms, such as Amgen and Chiron, are heavily involved in genomics as well. For example, Amgen was willing to pay as much as $\$ 90$ million, of which $\$ 20$ million was up front, to Rockefeller University for the rights to a recently discovered gene that may play a key role in obesity. Chiron licensed the exclusive rights to a gene mapping and sequencing technology developed at New York University (NYU) that could vastly speed the analysis of whole human genomes.

A recent report in an excellent industry newsletter [BioWorld Financial Watch, 1995] notes that the most active players in genomics are the independent, "little" biotechs-firms such as Millennium and Sequana Therapeuticsthat have "far-reaching collaborations with academic institutions ... (p. 1). Included among their various partners are university researchers, research clinics and hospitals, nonprofit institutes, and medical foundations. This broad array of partners spanning institutions typifies the cutting-edge areas of life sciences, illustrating how the boundaries of the research community are being redrawn.

${ }^{6}$ These data came from the National Science Board [1996, p. 121]. 


\section{Changes in the Division of Labor}

We have stressed that academics played a critical role in biotechnology's emergence, that many leading professors have formed companies to advance and commercialize their research, and that biotech companies are closely aligned with university research. But researchers also routinely move back and forth between universities and biotech firms, professors take sabbaticals at companies, and most established biotech firms run postdoctoral fellowship programs. Cutting-edge research is now performed by intellectually and institutionally heterogeneous groups, and researchers at for-profit companies play a key role in the basic science. The 1993 Nobel Prize in chemistry went to Kary Mullis for work done at a biotech firm. Powell, Koput, and Smith-Doerr [1996] present data that illustrate the research clout of biotech firms (pp. 140-141). Table 2 ranks leading contributors to the literature in molecular biology and genetics, as measured by citations per publication. There are two notable features of the list - the relative absence of universities and the presence of two commercial firms, Genentech and Chiron, in the forth and fifth positions, respectively. Many of the most critical publications, as measured by citations, are now coming from nonacademic organizations and, in some cases, private firms. In short, the labor market for life scientists has been greatly expanded, and the cross-traffic between universities and industry is now so extensive that it is fair to consider biotech firms and universities as part of a common technological community.

Further evidence of this blurring or redefining of boundaries is apparent from a brief review of activities at two leading universities, Stanford and Johns Hopkins. Both schools play a preeminent role in life sciences scholarship and its commercialization. Stanford has been notable for the key contribution its faculty played in the development of gene splicing, which made biotechnology possible, and in the large number of linkages between Stanford faculty and biotech companies. Hopkins has attracted attention for its novel efforts to commercially exploit the research prowess of its faculty and the inventive financial arrangements it has negotiated with commercial entities.

In 1973, Stanley Cohen of Stanford and Herbert Boyer of the University of California at San Francisco created the first recombinant DNA clone, thus making genetic engineering practical. They worked out a clear way to transplant genes from different organisms into bacteria, which then could be grown in

Table 2. Top ten most visible institutions in molecular biology and genetics: 1988-1992.

\begin{tabular}{lcc}
\hline Institution & Cites per publication & Number of papers \\
\hline Salk Institute & 41.6 & 403 \\
Cold Spring Harbor Labs & 40.8 & 359 \\
Whitehead Institute & 39.7 & 392 \\
Genentech & 33.1 & 225 \\
Chiron & 32.8 & 200 \\
Institute Chemie Biologique & 31.8 & 261 \\
Fred Hutchinson Cancer Center & 27.1 & 413 \\
Massachusetts Institute of Technology & 25.8 & 1060 \\
Princeton & 24.0 & 369 \\
MRC Lab Molecular Energy & 23.7 & 430 \\
\hline
\end{tabular}

Source: Powell, Koput, and Smith-Doerr [1996, p. 141]. 
large quantities. Boyer went on to play a founding role in the establishment of Genentech, the first widely known biotech company, and one that created enormous attention in October, 1980, when the company went public in a frenzied stock offering. Cohen remained at Stanford, where the university obtained a patent on their gene splicing technique, a valuable piece of intellectual property that earned Stanford and the University of California-San Francisco $\$ 66.3$ million each between 1980 and August 1996 [Puzzanghera, 1997, p. 12A]. Etzkowitz and Webster [1995] remark that Stanford created the organizational arrangements that promoted the view that high-quality science and generating money were complementary (p. 489). At Stanford's Office of Technology Licensing, Neils Reimers persuaded first Cohen and then Boyer to patent their work. Cohen (quoted in Etzkowitz and Webster [1995]) reports some initial reluctance: "My initial reaction to Reimers' proposal was to question whether basic research of this type could or should be patented and to point out that our work had been dependent on a number of earlier discoveries by others . . . Reimers insisted that no invention is made in a vacuum and that inventions are always dependent on prior work by others" (p. 489). Reimers later advised both MIT and the University of California on the setup of their technology transfer offices [Matkin, 1990].

At Johns Hopkins Medical School, an internal venture capital fund has been created to bankroll promising lines of research and move them toward commercialization. Adopting the view that the university can play the role of venture capitalist with more acumen and not have to share the gains with outsiders, faculty compete internally for venture funds. Hopkins has also "pushed the commercialism envelope" in other ways, such as licensing prior to discovery. For example, the Medical School approached Oncor Inc., a cancer-based biotech firm, and persuaded it to fund research in the newly established laboratory of a leading scientist in return for first rights to discoveries that might eventuate from the research. Moreover, of the more than $\$ 1$ million that Oncor paid Hopkins over a 3-year period, about 20 percent was in Oncor stock. Hopkins has aggressively pursued corporate funding of campus-based research. In the process of this commercial expansion, the university has also replaced Bethlehem Steel and Westinghouse Electric as Maryland's largest private employer.

\section{KEY FACTORS DRIVING THESE DEVELOPMENTS}

The changes underway in life sciences research are far-reaching. Most participants are surprised, even astonished, at the speed and extent of these transformations. The life sciences are going through a profound intellectual revolution, just at the time federal, corporate, and university policies are changing in response to new economic and political conditions. Consequently, developments in the life sciences are playing an important role in the process of creating new institutional mechanisms to respond to these changes.

\section{Expanding Opportunities, Not Resource Scarcity}

In contrast to many other areas of academic research, the life sciences do not suffer from declining resources. Recall Figure 1 that showed a steep rise in the outlay of both federal and industrial support for health sciences research. The life sciences presently receive more than 55 percent of all federal research support. The NIH is now by far the largest supporter of academic research, and 
between 1981 and 1990, its budget increased by 50 percent (in constant dollars), a figure two thirds greater than the increase in total federal outlays. At the end of the 1980s, the government began to fund the Human Genome Project at the rate of 3 billion dollars over 15 years. In fiscal year 1996, while most branches of government limped along on partial and continuing funding extensions, the NIH received a firm commitment from the Congress and the president, with a 5.6 percent increase, the largest in the federal budget. And, more recently, the 1997 appropriations bill gives the NIH an increase of 6.9 percent to a budget of $\$ 12.7$ billion [Marshall and Lawler, 1996].

Increased budgets do not, of course, necessarily keep pace with the costs of doing research, especially in fast-developing fields. Moreover, the number of life scientists competing for funds has certainly increased, intensifying the competition. But the overall financial picture in the life sciences looks promising in contrast to other areas of basic research. The motivations in this field are not driven by a lack of resources, we submit, but rather by the opportunity to expand the pool of available research funds-the chance to develop a new line of research more rapidly, to pursue a promising idea in order to speed the development of a new treatment that will either improve or save patients' lives. Indeed, there is growing evidence that commercial and basic funding go handin-hand. David Blumenthal [1992] and his colleagues [Blumenthal et al., 1996] report that scientists receiving support from biotechnology companies are the same researchers who also receive federal funds. Rather than a partitioning of the field into scientists with industry support on the one hand and those with federal monies on the other, we see the Matthew effect in operation: to those that already have, more shall be given [Merton, 1968].

At an institutional level, we find-not surprisingly-the same pattern. The universities most involved in the new biotechnology are among the wealthiest and most prestigious research universities. They are precisely where the centers of excellence in life science research are located. Our research indicates considerable overlap between the universities holding the largest number of formal contractual agreements (including licensing, long-term research partnerships, and large-scale clinical trials) with dedicated biotechnology companies, and those with the most accomplished research programs in the life sciences. Table 3 lists the universities with the most collaborations with

Table 3. Universities with the most formal contractual agreements with biotechnology companies: 1988-1995, and National Research Council (NRC)/National Academy of Sciences (NAS) Ranking.

1995 NRC/NAS graduate school ranking in molecular

\begin{tabular}{clc} 
and general genetics & \multicolumn{1}{c}{ Institution } & Collaborations \\
\hline 5 & Stanford University & 16 \\
3 & Harvard University & 11 \\
1 & Massachusetts Institute of Technology & 11 \\
9 & Johns Hopkins University & 10 \\
$2,6,10$ & University of California & $10^{\mathrm{a}}$
\end{tabular}

Sources: Powell, unpublished data derived from Bioscan, 1988-1995; National Research Council/ National Academy of Sciences rankings of leading U.S. graduate programs by field of study, 1995.

aThe University of California (UC) system is treated as a single entity because contracts from all campuses are signed with the board of regents; UC-San Francisco was ranked second, UC-San Diego sixth, and UC-Berkeley tenth in the NAS/NRC rankings. 
biotechnology firms, and shows that these schools are also those with the strongest graduate programs in molecular biology.

We think that this convergence reflects a change in the nature of knowledge, one that has not been sufficiently stressed nor its ramifications fully recognized. Thoughtful commentators such as Drucker [1993] and Nonaka [1994] have argued that a transformation, equivalent in scope to the Industrial Revolution, is underway in which the leading edge of the economy is more and more dependent on the production of knowledge. We make a less grand claim, but one with broad implications. The life sciences represent an area in which established conceptions of knowledge and existing institutional arrangements no longer adequately fit with the current methods for the production and commercialization of science. We see this change in the collapse of the distinction between basic and applied science, in the growing diversity of sources of expert knowledge, and in the complex interdisciplinary and multi-institutional teams needed to pursue cutting-edge research. As Powell and Smith-Doerr [1994] have argued, knowledge is increasingly located in networks of relationships, and access to such networks is a key to competitive survival. Recognition of this change in the location and organization of expertise means that it is inappropriate and misleading to focus only on changes in the organization of universities, without examining how changes in universities dovetail with simultaneous changes in private sector R\&D, federal policy, and the evolving structure of science. In short, we must view cutting-edge science as the product of a coevolutionary system of interlinked institutions.

Gibbons et al. [1994] describe a shift in the production of knowledge from a traditional disciplinary basis, which they term Mode I, to a more diffuse, interdisciplinary project, labeled Mode II. Well-understood extensions of existing knowledge, with eventual applied commercial applications, typify Mode I. Several of the earliest university commercial endeavors, like agriculture, chemical engineering, mining and metallurgy, are exemplars of Mode I. Gibbons et al. [1994] argue that Mode I knowledge is organized around established disciplines, where intellectual development is linear. Commercial applications occur "downstream," and innovations involve breakthroughs in scale. Mode II knowledge, they suggest, is exemplified by biotechnology, high-energy physics research in the area of superconductivity, and the marriage of computers, software, and telecommunications being played out today on the World Wide Web. These forms of knowledge span disciplines, are more commonly organized through networks than collegial hierarchies, and are characterized by rapid, often nonlinear development. Consequently, the internal dynamics of science have generated a new system of knowledge production, in which greater interdisciplinarity and more collaboration are key features.

Although the Mode I/Mode II distinction is a broad characterization, we find it is an apt description of the revolution in the nature and use of knowledge in the life sciences. Recall the changes in the most active areas of university patenting, from harvesters and measurement devices to the life sciences. Remember also that leading biotechnology firms, as well as nonprofit research institutes, now play a significant role in producing and publishing cutting-edge research. At the same time, industry research in established pharmaceutical companies has become much more theory-based, model-driven, and deductive than earlier methods of trial-and-error search and inductive reasoning. Breakthrough research involves the collaboration of multiple disciplines and heterogeneous institutions. Consider the 1992 Oliver et al. article in Nature, that re- 
ports the sequencing and characterization of an entire yeast chromosome. (Yeast has many genes that are homologous to humans and has a fairly "simple" structure that makes it highly useful for inserting foreign genes for amplification.) This exceedingly laborious and important work involved $141 \mathrm{sci}$ entists from more than 35 nonprofit, public, and private institutions from around the globe. Or examine any one of a number of publications in Science on BRCA1, the gene that plays a critical role in familial breast and ovarian cancers. For example, the 7 October 1994 article, "BRCA1 Mutations in Primary Breast and Ovarian Carcinomas," has 27 authors located at the NIH, a new biotech company, a new department of medical informatics at the University of Utah Medical Center, a Swedish university, Sloan-Kettering Cancer Center, and two departments at Duke University. These articles vividly illustrate the changing locus of knowledge, and how intellectual progress depends on collaboration across disciplinary and institutional boundaries.

We contend that the boundaries between universities and firms in the life sciences are crumbling. These new organizational arrangements blur the distinction between academic research and commercial development. Life sciences research not only spans disciplines and organizations but increasingly fuses knowledge and property. Stephan [1994] has shown that the success of initial public offerings of biotech firms is significantly related to the reputation of university scientists affiliated with the firm. At the same time, the annual reports of university research offices look like documents prepared for the private sector, while biotech firm annual reports could pass as grant reports to the NIH. The strong precommitment to different norms and rewards, stressed by researchers in the economics and sociology of science [Dasgupta and David, 1987, 1994; Merton, 1957, 1968, 1988] also appears to be declining as the realms of science and technology become inseparable.

\section{CONSEQUENCES OF THE NEW MANDATE FOR UNIVERSITIES}

As university management of intellectual property becomes more aggressive and far-reaching, and as universities become regarded as key contributors to economic growth, they become enmeshed in a wide array of political and economic relationships. This broader role of universities engages many more political constituencies and interest groups, and, in turn, creates new expectations while making it much more difficult for universities to maintain their legitimacy. Nobel Laureate Philip Sharp, former director of MIT's Center for Cancer Research, worries that the desire to harness the commercial potential of universities has led to the earmarking of federal research funds to particular local institutions. Such political decisions threaten to reduce the influence of merit review. Sharp [1994] cautions that: "As universities become more identified with commercial wealth, they also lose their uniqueness in society. They are no longer viewed as ivory towers of intellectual pursuits and truthful thoughts, but rather as enterprises driven by arrogant individuals out to capture as much money and influence as possible" (p. 148).

We focus first on how the new mandate for universities has triggered the use of "earmarking," or the award of special purpose funds by Congress without the use of a peer review process. The pursuit of new revenues has also led to significant organizational changes in the structure of universities. There is growing evidence of an academic arms race, resulting in a division between 
Table 4. Congressional earmaking for universities and colleges: total funds by year, 1980-1993.

\begin{tabular}{lrr}
\hline Year & Number of earmarks & \multicolumn{1}{c}{ Amount } \\
\hline 1980 & 7 & $10,740,000$ \\
1981 & 0 & 0 \\
1982 & 9 & $9,370,999$ \\
1983 & 13 & $77,400,000$ \\
1984 & 6 & $39,320,000$ \\
1985 & 39 & $104,085,000$ \\
1986 & 38 & $110,885,000$ \\
1987 & 48 & $163,305,000$ \\
1988 & 72 & $232,392,000$ \\
1989 & 208 & $299,026,000$ \\
1990 & 252 & $247,976,333$ \\
1991 & 279 & $470,279,499$ \\
1992 & 499 & $707,989,031$ \\
1993 & NA & $763,000,000$ \\
Totals & 1422 & $3,235,768,862$ \\
\hline
\end{tabular}

Source: National Science Board [1993, p. 139].

the haves and have nots. Many commentators have questioned whether commercial activities compromise scientific impartiality by introducing the profit motive into research [Brooks, 1993; Krimsky, 1991]. We stress a less direct, second-order effect of increased commercialization: the potential for university and faculty interests to be at odds with one another. Finally, we discuss how changes in the mandate of universities have led to disputes over the values and the very culture of university life. We illustrate these issues with a discussion of the different issues raised by patenting and publishing.

\section{Politics of Funding}

The trend of shifting research funds away from scientific peer review toward the more overtly political field of congressional earmarking is suggested by the growth of earmarked funds noted in Table 4. The expansion of earmarked funds has been dramatic, from $\$ 11$ million in 1980 to $\$ 708$ million in 1992 , coinciding with the birth and development of biotechnology. Merit review plays no role in the earmarking process. Traditionally, earmarked funds were used for the construction of university facilities, but by 1992, 42 percent of earmarked funds went for university research. Put differently, Congress provided almost $\$ 300$ million to university researchers in 1992 without making any attempt at intellectual assessment [Pennisi, 1993].

Debates over earmarking are typically loud and bitter. Critics argue that the process is dominated by special interest politics and extensive lobbying, and results in lower quality science while simultaneously denying merit-based funding to more worthy projects. Supporters of earmarking, such as former Boston University President John Silber, defend their large payments for lobbying activities, claiming earmarking represents a way to "level the playing field."7 Silber charges that the peer process is a "tight knit old-boys network,"

${ }^{7}$ Boston University paid Cassidy and Associates, the most renowned academic lobbying firm, $\$ 7.9$ 
and "an oligopoly." 8 Earmarking, Silber opines, "is the ante that gives places like Boston University a seat at the table, and the last thing those (elite) institutions want is an aggressive new player in their game." Boston University (BU) received a total of $\$ 56.5$ million in earmarked funds in 1984, 1988, and 1992, to build research centers in physics and engineering. In turn, BU's success in obtaining competitive grants increased by "647\%" [U.S. Congress, House of Representatives, 1993, p. 231]. The grants also brought important economic benefits to the local community, in construction jobs and subsequent employment, a point BU, as well as other universities such as Northwestern, emphasized in their congressional testimony in support of earmarking.

\section{Organizational Responses}

The pursuit of new sources of revenue, from either the commercial marketplace or the political arena, has led to a number of organizational adaptations within universities. The 1992 U.S. GAO report on university research noted that 34 of the 35 surveyed institutions, having substantially expanded their patent and licensing programs since 1980, had established a technology licensing office, whereas in 1980 only 22 had such an office. The spread of technology transfer offices, the fees paid to lobbying firms, and the legal expenses associated with defending intellectual property are all costs associated with new forms of academic entrepreneurship.

Earlier we noted that the commercial firms best able to exploit new technological breakthroughs are those with the most extensive external connections and the strongest internal capabilities for evaluating research done elsewhere [Powell, Koput, and Smith-Doerr, 1996]. The same process appears to hold for universities, with several consequences. One effect is an increasingly sharp division between academic haves and have nots. Research funding is already highly concentrated. Schultz [1996] reports that 85 percent of federal research funding-about $\$ 13$ billion in 1992-goes to 100 research universities and 21 percent of that funding goes to just 10 universities (p. 133). These same universities are in the forefront of commercialization efforts. A second-order effect is found in the considerable efforts on the part of universities to develop institutional arrangements to foster external linkages (such as industrial liaison programs, contract research agreements, research parks, clinical trials programs, and the like) and internal administrative capabilities to facilitate them (such as offices of sponsored research, technology transfer, patent administration, institutional development, large legal departments, and the like). Matkin [1990] evaluates the technology transfer offices of four research universities, finding marked differences in how their "commercialization arms" are organized. We know little at this point about the commercial efficacy of different forms of university organization, but we suggest that a third-order effect of enhanced commercial efforts is to change the calculus by which political and economic leaders evaluate universities.

million over the period 1981-1994 [U.S. Congress, House of Representatives, 1993, p. 389]. Northwestern University, also highly successful in obtaining earmarked funds (portions of which went to support a biotechnology center), paid Cassidy and Associates \$3.7 million from 1984-1994 (p. 198).

${ }^{8}$ Partially stemming from criticisms raised at the congressional earmarking hearings, the U.S. GAO conducted a detailed study of peer review at the NSF and NIH in 1993, finding little evidence of bias [Marshall, 1994] 
The various on-campus offices and off-campus programs established to promote and process commercial endeavors are not inexpensive to operate. Intellectual property law is a burgeoning and expensive field, and patent applications incur considerable costs and time to file and even more so to enforce. And there seems to be a wholesale rush in this direction by all universities, triggering a form of status-based competition in which universities show the symbols, if not the fruits, of commercial efforts. But even though many universities are attempting to develop internal competencies at commercialization, we suspect that the lion's share of the results will go to a small handful of universities with the strongest basic science research portfolios. As the academic race for commercial support heats up, a winner-take-all market results [Frank and Cook, 1995]. Those universities not in the vanguard will find themselves comparatively much poorer, losing out in competitions for new facilities, up-and-coming faculty, promising graduate students, and research funding.

\section{Conflicting Interests}

Commercial activities do more than generate revenues. Universities in the forefront of life sciences research will undergo heightened scrutiny and criticism as they attempt to chart a course in unfamiliar waters. The reality, however, is that there is no turning back to a less complex and contradictory era. The emerging discoveries in the life sciences are so powerful and dramatic, and the medical and material rewards so considerable, that each new scientific discovery represents yet another commercial opportunity. There have been only limited efforts to assess the consequences of these developments on the internal culture of universities. Most attention has focused on the individual faculty members and whether the integrity of their scientific research is compromised by commercial efforts [National Academy of Sciences, National Academy of Engineering, Institute of Medicine, 1992]. A few observers recognize that the new environment creates competing claims: research for knowledge; research for treatment; and research for competitive advantage [Trias, 1996]. Indeed, some university administrators argue that "conflicts of interest aren't bad; they're good." Craig Heller, Stanford's associate dean of research, argues that conflicts mean "you have an entrepreneurial environment. It has to be recognized and managed" [Puzzanghera, 1997, p. 13A].

Universities, aware of the potential conflicts between advancing knowledge and generating revenues, are struggling to develop rules of conduct that simultaneously_-some would say incompatibly-safeguard faculty from commercial pressures, mandate disclosure of possible conflicts of interest, and provide incentives to faculty working in areas with commercial potential. But what protects faculty when the university represents its interests in external commercial negotiations rather than those of the researcher whose work is being marketed? There are numerous disputes between faculty members who prefer an accessible open license for their discovery, which would maximize the breadth of knowledge dissemination, and universities that seek a more lucrative, exclusive license. Who is the fiduciary when universities convert a professor's discovery into equity ownership in a company, and that company is subsequently sued for patent infringement? A current legal case in California illustrates the possible conflicts between universities and their faculty. Two professors won a jury award of $\$ 2.3$ million from the University of California-San Francisco, after claiming it defrauded them by licensing their patents to other 
companies at a discount in exchange for sponsored research support from those companies. Thus, for all the attention to possible faculty conflicts of interest, a parallel caution is needed: the growing opportunity for faculty and university interests to diverge.

The broadest ramification of the new conception of knowledge as property may be its capacity to change the culture of academic life. The author of a recent back-page essay in Scientific American observes that, “. . . when today's professors hit the big time, they have to read their professional literature and Business Week, write scientific papers and patent applications, teach, give seminars, and sit on the scientific advisory boards of various corporations" [ZollaPazner, 1994, p. 120; emphasis in the original]. The author, a professor of pathology at NYU Medical Center, goes on to remark that:

The academic scientist finds herself taking a crash course in business and law. The demands of negotiating agreements and writing patents drain time and energy. Some research activities are redirected from basic science toward more immediately practical goals. The promise of continuing industrial support is seductive but inevitably tied to commercial products and the bottom line. The lab may find itself focused on an agenda set by the company. The basic research that sparked the initial effort may lie fallow. The spontaneity of scientific pursuit, so prized by those lucky enough to have investigatorinitiated government research grants, may be restricted. The speed with which the professor can share data or new reagents may be slowed. The result, in the worst scenario, would be deleterious for the lab, harmful for science, bad for society. (p. 120)

We doubt that such a wholesale appropriation of a scientist's research agenda is likely, particularly when there is evidence that scientists who are successful in one arena, such as federal grants, also fare well in commercial areas. But the focus of research can be shaped in subtle ways by commercial exigency rather than scientific curiosity. Feller [1990] and Cohen and Noll [1994] argue strongly that academic research is now more directed toward questions whose answers constitute "patentable" or commercial outcomes. Feller goes on to suggest that faculty working on the "newer" scientific questions are more intensively involved in the postdiscovery stages of research; in one respect, this means that faculty now exert more control over the terms and means by which academic research moves to the marketplace. Many would regard this development as positive, but few would be satisfied if its consequence was that the merits of faculty research were judged according to its commercial significance.

In an important new study, Packer and Webster [1996] analyze the emergence of a patenting culture in British universities, and stress that the making of claims for patenting departs notably from traditional conceptions of novelty in science. Patenting involves demonstrating to an imaginary person-the legal fiction of a "person skilled in the art" - that a discovery would not have been an obvious extension of existing knowledge or practice. The universe of patenting, Packer and Webster [1996] observe, is a virtual one in which no one has "membership" status even when one participates in it (p. 438). Patenting does not just involve different rules from academic publishing, it is a different game altogether. Writing papers and building an audience for one's ideas involves enrolling other academics in a collective project; patenting has more to do with controlling others. Put differently, patenting involves claims staking; publishing entails claims making. "Holding patents is not so much a means of enhancing the credibility of scientists in their research world but a means of 
defending prior investment in the area" (p. 441). For centuries, scientists have done their research virtually unfettered by patent constraints. Now, worries Stanford professor and Nobel Laureate Arthur Kornberg, "Every one of us working in a laboratory ... have to wonder whether anything we do may have been protected by a patent and whether we will be sued for it" [Carlton, 1995, p. B4].

\section{CONCLUSION}

We have argued that a profound blurring of the roles of universities and private industry is developing in the life sciences, and that these changes have broad consequences for research universities. We contend that these changes are, in large part, irreversible because they reflect a significant transformation in the nature of knowledge. We agree with Hicks and Katz [1996] that "research collaboration among geographically-separated institutions will become the normal way of conducting research-the rule, not the exception" (p. 394). We add that in the life sciences such collaboration spans the academy, private industry, nonprofit research institutes and hospitals, and government laboratories, and we see these institutions as coevolving in ways that make them organizationally more similar.

These developments offer ample opportunities for universities to diversify their funding base, and to contribute to both the advancement of life sciences research and the development of powerful new medicines that will be of considerable benefit to society. At the same time, the ramifications of the growing parallels in the organization of the academy and industry, and the role of federal policy in promoting these trends, are poorly understood. Already Feller [1990] has observed that many academic research teams have the character of "quasi-firms" as scientists eagerly pursue R\&D programs aimed at commercial application. To the extent that the norms of open science are fragile [Dasgupta and David, 1994], universities may well be endangering their distinctive reward systems. Changes in the reward system (such as tying salary increases or tenure to success at research commercialization) could result in a loss of legitimacy, or speed the movement of scientists to other institutions. Either development would impair the educational mission of research universities. Moreover, the loss of researchers to industry could result in fewer basic scientific discoveries by universities, harming their research function. And as the cross-traffic between universities and industry increases, it becomes less apparent what will remain distinctive and appealing about a career of university-based research.

We also caution that universities are not well equipped as organizations to deal with the growing status of knowledge as property. Matkin [1994] contends that universities typically see the problems associated with commercialization as "isolated instances of bad judgement or bad luck, and call for ad hoc solutions," rather than comprehending that these problems are outcroppings of a deeper transformation (pp. 382-383). We add that of all the participants in the new highly linked universe of knowledge development and commercialization, it is universities whose established routines of operation will be most transformed. If practices fundamental to the traditional mission of universities are altered in a piecemeal fashion, without recognition of the deeper and more systemic changes we describe, the potential for distortion of the goals of universities is considerable. We also stress that changes in operating routines 
made to accommodate technological developments in the life sciences might have unanticipated consequences when applied to other sectors of the university. Given that the areas of knowledge that we characterize as Mode II-where intellectual breakthroughs have immediate commercial relevance-represent only a limited portion of university research, the life sciences may not be an appropriate model for all university technology transfer activities.

Enhanced efforts at commercialization typically lead universities to devolve financial responsibility to lower levels, allowing individual research units autonomy and responsibility for their own funding. As this process unfolds, market-based criteria become the dominant logic in resource allocation decisions. Current trends clearly point in the direction of this more instrumental focus on resources, even though funding opportunities that are abundant today may be less plentiful in the future. In contrast to the long-term steady support for research provided by the federal government, future sources of funding are likely to be much more variable and dictated by commercial need. In the life sciences, we note that market criteria do not discriminate between medical and nonmedical goals. To date, the great bulk of biomedical research has focused on unmet medical needs. But there are many areas, such as obesity and human dwarfism, where highly lucrative research applications might be based more on cosmetic considerations.

The changes underway at research universities are the result of multiple forces - a transformation in the nature of knowledge, and a redefining of the mission of universities by both policymakers and key constituents. These trends are so potent that there is little chance for reversing them, nor necessarily a rationale to do so. Nevertheless, without recognition of the confluence of forces that are spearheading increased efforts at commercializing research, university responses are likely to be incremental and inadequate. It must be recognized that the conditions that have given rise to the commercialization of basic research in the life sciences are idiosyncratic to this field. Moreover, changes that entail the use of market-based criteria (such as more focus on patenting and licensing) to evaluate the "merits" of research may, in unanticipated ways, lead to a corrosion of the mission of research universities, undercutting public trust in these institutions. Such developments could, then, erode the very features that have made U.S. research universities unparalleled contributors to both intellectual and commercial advance.

We thank Avner Ben-Ner, Allen Buchanan, Christian Freuh, Laurel Smith-Doerr, Sarah Soule and Burton Weisbrod for comments on an earlier draft. The first author acknowledges the research support provided by the Aspen Institute Program on Nonprofit Research and NSF Grant No. 9710729.

WALTER W. POWELL is Professor of Sociology at the University of Arizona.

JASON OWEN-SMITH is a graduate student in Sociology at the University of Arizona.

\section{REFERENCES}

Audretsch, David B. and Paula E. Stephan (1996), “Company-Scientist Locational Links: The Case of Biotechnology,” American Economic Review 86(3), pp. 641-652. 
Badaracco, Joseph (1991), The Knowledge Link (Boston: Harvard Business School Press).

Ben-David, Joseph (1977), Centers of Learning: Britain, France, Germany, and the United States (New York: McGraw-Hill).

BioWorld Financial Watch (1995), newsletter, September 25.

Blumenthal, David (1992), “Academic-Industry Relationships in the Life Sciences: Extent, Consequences, and Management," Journal of American Medical Association 268(23), pp. 3344-3349.

Blumenthal, David, Nancyanne Causino, Eric Campbell, and Karen Seashore Louis (1996), "Relationships between Academic Institutions and Industry in the Life Sciences-An Industry Survey," The New England Journal of Medicine 334(6), pp. 368373.

Brooks, Harvey (1993), "Research Universities and the Social Contract for Science," in Lewis M. Branscomb (ed.), Empowering Technology (Cambridge, MA: MIT Press).

Carlton, James M. (1995), "Roche Brings Leading Institutions into Lawsuit over Patent Rights,” The Wall Street Journal, May 25, p. B4.

Chubin, Daryl E. (1994), "How Large an R\&D Enterprise?” in David H. Guston and Kenneth Keniston (eds.), The Fragile Contract: University Science and the Federal Government (Cambridge, MA: MIT Press).

Cohen, Linda R. and Roger G. Noll (1994), "Privatizing Public Research,” Scientific American (September), pp. 72-77.

Cohen, Wesley, Richard Florida, and Richard Goe (1994), University-Industry Research Centers in the U.S. (Pittsburgh; PA: Carnegie-Mellon University Press).

Cole, Jonathan R. (1993), "Balancing Acts: Dilemmas of Choice Facing Research Universities," Daedalus 122(4), pp. 1-36.

Dasgupta, Partha and Paul David (1987), "Information Disclosure and the Economics of Science and Technology," in George R. Feiwel (ed.), Arrow and the Ascent of Modern Economic Theory (New York: New York University Press).

Dasgupta, Partha and Paul David (1994), “Toward a New Economics of Science,” Research Policy 23(5), pp. 487-521.

Drucker, Peter (1993), “The Rise of the Knowledge Society,” Wilson Quarterly (Spring), pp. 52-71.

Etzkowitz, Henry and Andrew Webster (1995), "Science as Intellectual Property," in Shelia Jasanoff, Gerald Mankle, James Peterson, and Trevor Pinch (eds.), Handbook of Science and Technology Studies (Thousand Oaks, CA: Sage).

Feldman, Maryann P. (1994), The Geography of Innovation (Boston: Kluwer).

Feldman, Maryann P. and Richard Florida (1994), "The Geographic Sources of Innovation," Annals of the Association of American Geographers 84(2), pp. 210-229.

Feller, Irwin (1990), "Universities as Engines of R\&D-based Economic Growth: They Think They Can," Research Policy 19, pp. 335-348.

Frank, Robert H. and Phillip J. Cook (1995), The Winner-Take-All Society (New York: The Free Press).

Geiger, Roger (1986), To Advance Knowledge: The Growth of American Research Universities, 1900-1940 (New York: Oxford University Press).

Gibbons, Michael, Camille Limoges, Helga Nowotny, Simon Schwartzman, Peter Scott, and Martin Trow (1994), The New Production of Knowledge (London: Sage).

Guterman, Sonia K. (1996), "Licensing Biotechnology from Universities," BioPharm (May), pp. 38-42. 
Hagedoorn, John (1993), "Understanding the Rationale of Strategic Technology Partnering," Strategic Management Journal 14, pp. 371-385.

Hamel, Gary (1991), "Competition for Competence and Inter-Partner Learning within International Strategic Alliances," Strategic Management Journal 12, pp. 83-103.

Henderson, Rebecca, Adam B. Jaffe, and Manuel Trajtenberg (1995), “The Bayh-Dole Act and Trends in University Patenting, 1965-1988," Center for Economic Policy Research, Paper No. 433, Stanford University, Palo Alto, CA.

Hicks, Diana M. and J. Sylvan Katz (1996), "Where Is Science Going?” Science, Technology, and Human Values 21(4), pp. 379-406.

Jaffe, Adam B., Manuel Trajtenberg, and Rebecca Henderson (1993), "Geographic Localization of Knowledge Spillovers as Evidenced by Patent Citations," Quarterly Journal of Economics 79(5), pp. 957-970.

Koput, Kenneth, Walter W. Powell, and Laurel Smith-Doerr (1997), “The Role of Elite Sponsorship in Biotechnology's Development," manuscript, University of Arizona.

Krimsky, Sheldon (1991), “Academic-Corporate Ties in Biotechnology: A Quantitative Study," Science, Technology, and Human Values 16, pp. 275-287.

Krugman, Paul (1991), "Increasing Returns and Economic Geography,” Journal of Political Economy 63(3), pp. 483-499.

Lee, Yong S. (1994), “Technology Transfer and Public Policy in an Age of Global Economic Competition,” Policy Studies Journal 22(2), pp. 260-266.

Marshall, Eliot (1994), “Congress Finds Little Bias in the System," Science 256(12 August), p. 863.

Marshall, Eliot and Andrew Lawler (1996), "Congress: Biomedical Research Wins Big," Science 274(4 October), pp. 27-28.

Matkin, Gary W. (1994), “Technology Transfer and Public Policy: Lessons from a Case Study," Policy Studies Journal 22(2), pp. 371-383.

Merges, Robert P. and Richard R. Nelson (1990), "On the Complex Economics of Patent Scope,” Columbia Law Review 90(4), pp. 839-916.

Merton, Robert K. (1957), "Priorities in Scientific Discovery: A Chapter in the Sociology of Science," American Sociological Review 22(6), pp. 635-659.

Merton, Robert K. (1968), “The Matthew Effect in Science," Science (January 5) 159(3810), pp. 56-63.

Merton, Robert K. (1988), “The Matthew Effect in Science, II: Cumulative Advantage and the Symbolism of Intellectual Property," Isis 79(299), pp. 606-623.

Mowery, David C. and Nathan Rosenberg (1993), "The U.S. National Innovation System," in Richard R. Nelson (ed.), National Innovation Systems: A Comparative Analysis (New York: Oxford University Press).

National Academy of Sciences (1992), The Government Role in Civilian Technology: Building a New Alliance (Washington, DC: National Academy Press).

National Academy of Sciences, National Academy of Engineering, Institute of Medicine (1992), Responsible Science: Insuring the Integrity of the Research Process, Vol. 1 (Washington, DC: National Academy Press).

National Science Board (1993), Science and Engineering Indicators-1993, NSB 93-1 (Washington, DC: U.S. Government Printing Office).

National Science Board (1996), Science and Engineering Indicators-1996, NSB 96-1 (Washington, DC: U.S. Government Printing Office).

Nelson, Richard R. (1990), “U.S. Technological Leadership: Where Did It Come from and Where Did It Go?” Research Policy 19, pp. 119-132. 
Nonaka, Ikujiro (1994), "The Dynamic Theory of Organizational Knowledge Creation," Organization Science 14, pp. 319-340.

Oliver, S. G., Q. J. M. van der Aart, et al. (1992), "The Complete DNA Sequence of Yeast Chromosome III," Nature 357, pp. 38-46.

Packer, Kathryn and Andrew Webster (1996), "Patenting Culture in Science: Reinventing the Scientific Wheel of Credibility," Science, Technology, and Human Values 21(4), pp. 427-453.

Pennisi, E. (1993), "Concern Grows over Expansion of Earmarking," Science News 144(8)(August 21), p. 119.

Powell, Walter W. (1990), "Neither Market Nor Hierarchy: Network Forms of Organization," in Barry M. Staw and L. L. Cummings (eds.), Research in Organizational Behavior, Vol. 12 (Greenwich, CT: JAI Press).

Powell, Walter W. (1996), "Interorganizational Collaboration in the Biotechnology Industry," Journal of Institutional and Theoretical Economics 152(1), pp. 197-216.

Powell, Walter W. and Laurel Smith-Doerr (1994), "Networks and Economic Life" in Richard Swedberg and Neil J. Smelser (eds.), Handbook of Economic Sociology (Princeton, NJ: Princeton University Press).

Powell, Walter W., Kenneth Koput, and Laurel Smith-Doerr (1996), "Interorganizational Collaboration and the Locus of Innovation: Networks of Learning in Biotechnology," Administrative Science Quarterly 41(1), pp. 116-145.

Puzzanghera, Jim (1997), "How Federal Funds Fueled DNA Research," San Jose Mercury News, May 5, pp. 1A, 12-13A.

Roessner, J. David and Anne Wise (1994), "Public Policy and Emerging Sources of Technology and Technical Information Available to Industry," Policy Studies Journal 22(2), pp. 349-358.

Romer, Paul (1986), "Increasing Returns and Long-Run Growth," Journal of Political Economy 94(5), pp. 1002-1037.

Rosegrant, Susan and David Lampe (1992), Route 128: Lessons from Boston's High-Tech Community (New York: Basic).

Rosenberg, Nathan and Richard R. Nelson (1994), "American Universities and Technical Advance in Industry," Research Policy 23, pp. 323-348.

Rosenbloom, Richard S. and William J. Spencer (1996), "The Transformation of Industrial Research," Issues in Science and Technology XII(3), pp. 68-74.

Saxenian, Annalee (1994), Regional Advantage (Cambridge, MA: Harvard University Press).

Schriesheim, Alan (1990-1991), "Toward a Golden Age of Technology Transfer," Issues in Science and Technology (Winter), pp. 52-58.

Schultz, Jerome (1996), "Interactions between University and Industry," in Frederick B. Rudolph and Larry W. McIntire (eds.), Biotechnology (Washington, DC: Joseph Henry Press).

Sharp, Phillip A. (1994), "The Biomedical Sciences in Context" in David H. Guston and Kenneth Keniston (eds.), The Fragile Contract: University Science and the Federal Government (Cambridge, MA: MIT Press).

Slaughter, Sheila and Gary Rhoades (1996), "The Emergence of a Competitiveness R\&D Policy Coalition and the Commercialization of Academic Science and Technology," Science, Technology, and Human Values 21(3), pp. 303-339.

Smilor, Raymond W., George Kozmetsky, and David Gibson (eds.) (1988), Creating the Technopolis: Linking Technology, Commercialization, and Economic Development (Cambridge, MA: Ballinger). 
Stephan, Paula E. (1994), "Differences in the Post-Entry Value of Biotech Firms: The Role of Human Capital," unpublished manuscript, Georgia State University, Atlanta, GA.

Stephan, Paula E. (1996), “The Economics of Science,” Journal of Economic Literature 34(September), pp. 1199-1235.

Stigler, Stephen M. (1993), “Competition and the Research Universities," Daedalus 122(4), pp. 157-178.

Trias, José (1996), “Conflict of Interest in Basic Biomedical Research,” in Frederick B. Rudolph and Larry W. McIntire (eds.), Biotechnology (Washington, DC: Joseph Henry Press).

U.S. Congress, House of Representatives (1993), “Academic Earmarks-Part III,” Hearings before the Committee on Science, Space, and Technology, September 21, 22, and October 6.

U.S. Congress, Senate, Subcommittee on Patents, Copyrights, and Trademarks (1994), The Bayh-Dole Act: A Review of Patent Issues in Federally Funded Research (Washington, DC: U.S. Government Printing Office).

U.S. General Accounting Office (U.S. GAO) (1992), "University Research: Controlling Inappropriate Access to Federally Funded Research Results," GAO/RCED-92-104, May.

Von Hippel, Eric (1988), Sources of Innovation (New York: Oxford University Press).

Zolla-Pazner, Susan (1994), "The Professor, the University, and Industry," Scientific American (September), pp. 72-77.

Zucker, Lynne G., Michael R. Darby, and Marilynn B. Brewer (1994), "Intellectual Capital and the Birth of U.S. Biotechnology Enterprises," National Bureau of Economic Research, working paper no. 4653. 